\title{
Code Switching Analysis in THe Notes Made by THe SaleS ASSISSTANTS IN RIPCURL
}

\author{
Ni Made Verayanti Utami, Dikril Hakim, I Nyoman Prasetya Adiputra \\ STIBA Saraswati Denpasar
}

verayanti.utami@gmail.com, Dikrilhakim169@yahoo.com, Kokopras39@yahoo.co.id

\begin{abstract}
Language is very important means of communication. It is used to communicate and to give information to others. There are many languages in the world that people can choose their interaction. Choosing one proper language in communication is very important to avoid misunderstanding. People have to choose a particular language and or decide to switch from one to another. The switch from one language to the other one called as code switching. Code switching may occurred in many areas. One of them is tourism area. Thus, the aims of this research to identify the types of code switching, to analyze the function of the code switching and to find out the factors led the sales assistants code-switch. The data source was taken from the log book of Ripcurl (surf shop) that is written by the sales assistants. The data was collected through observation method through note taking techniques. The log book was read and the expressions represent the use of code switching were noted. After the data collected, they were analyzed. Descriptive qualitative method was used to analyze the data. The analysis was conducted through several steps. First, the theory proposed by Poplack (1989) was used to classify the types of code switching produced by Nusa Dua Ripcurl log book. Furthermore, the theory of the function of code switching developed by Apple and Muysken (1987:118-120) was used to analyzed the function of code switching. The results of the analysis shows that there are three types of code switching found in the notes made by the staffs in Ripcurl Nusa Dua namely tag switching, inter-sentential switching, and intra-sentential switching. In terms of the function of the code switching, it is found that not all of six functions were available. Metalinguistic function, referential function and phatic function were applicable found in the notes made by the staffs in Ripcurl Nusa Dua. Last, the factors led the staff code switch is because the staffs found that the English term is easier to remember or better to be understood than in Indonesian term.
\end{abstract}

Keywords: code switching, log book note

\section{INTRODUCTION}

Language is very important means of communication. It is used to communicate and to give information to others. There are many languages in the world that people can choose their interaction. People have to choose a particular language and or decide to switch from one to another. The use of English in tourism business creates many kinds of phenomenon. One of them is Code-switching. A research in code switching is a study to understand why do people who are competent in two languages alternate in a particular conversation or situation. Code switching is generally a phenomenon when a bilingual and multilingual speaker shifts from one language to another in the course of conversation. Code switching based on Grosjean (1982) suggests definition of code switching as the use of more than one language by communication in speech act. As a part of bilingualism code switching is commonly found in any conversation, teaching, learning, or the other kind of communications. Code switching is also usually found in the speeches of people who work in tourism industries such as surf shops, restaurants, hotels, etc.

In the tourism industries in Bali, code switching occur among the bilingual people either local or foreign who interact with each other. Ripcurl is one of the leading surf products in Bali among the tourists and local people who surf. Ripcurl has become a place where code switching occurs among the staff in doing verbal than interaction. At Nusa Dua surf shop lots of notes are made in the log book to inform the staff if there are new things that must be followed up. For example: "Dear all: Halloween is coming, jangan sampai ketinggalan ya". In the example of a note made by a Ripcurl staff above there is a code switching found in the sentence, there are two languages, English and Indonesian, combined "Dear all: Halloween is coming" is written in English and it is followed by Indonesian language "jangan sampai ketinggalan ya". This case of written bilingual communication is very interesting and important to be 
analyzed for some reasons because a sales assistant is indirectly doing "code switching" in making a note in the log book, it is probably because of their habit.

Related to the background as explained above, the research problems are the types of code switching found in the notes made by staff of Ripcurl, the functions of the code switching found in the notes made by staff of Ripcurl, and factors that leads the staff to do code-switch.

The research that is related to this study has been taken from three thesis. In this chapter, there are three different thesis that were reviewed. The first thesis is written by Oktavina (2013) entitled " $A n$ Analysis Of Code Switching Used By Hashim As A Character In Film Entitled Java Heat". In her thesis, the data sources were from film in the title Java Heat. Oktaviana used the theory of the types of code switching proposed by Poplack (in Romaine, 1989: 122 ) who distinguishes type of code switching into three, i.e., : tag switching, intra-sentential switching, and inter-sentential switching and Hoffman (1991) on functions of code switching in analyzing the data, qualitative approach method was applied. The result of her study showed two types of code switching happen in the film entitled Java Heat they are intersentential code switching and intra-sentential code switching, from the seven functions there are only six function can be found in the used of inter-sentential code switching and intra-sentential code switching happened in the film. They are talking about a particular topic being emphatic about something, interjection, repetition used for clarification, intention of clarifying the speech content for interlocutor and expressing group identity. Based on the analysis of the data, there are only five functions of intersentential function and five function of intra-sentential function. Oktavina's study is very useful as the reference for this study. It has the same concern on code switching which is used to reach the aims of study. Furthermore, the theory for analyzing the function of code switching is different since the theory by Hoffman (1991) was used in her study, while this study used the theory proposed by Apple and Musyken (1987). Nevertheless, her study can be used to improve knowledge in conducting this study.

The second thesis entitled "English Code Switching and Code Mixing Found in Advertisements of Kompas in the week of July Edition 2011" which is made by Karimah (2011). In her thesis, she uses advertisements in Kompas as data sources. It was analyzed by using qualitative descriptive method. Karimah used the theory of the types of code switching proposed by Poplack (in Romaine, 1989: 122) who distinguishes type of code switching into three types, those are: tag switching, intra-sentential switching, and inter-sentential switching. The theory of Apple and Muysken (1987) on function of code switching was also used. The result of her study were, first the form of code switching is external code switching and the function of code switching are informational, directive, and expressive, the second is the form code mixing are: word, phrase, hybrid, and clause and the function of and code mixing are: informational, and directive. Karimah study is very useful as reference for this study. It has the same concern on code switching especially for the theory, which used to answer the problems of this study.

The last thesis made by Jehatu (2011) entitled "The Analysis of Code Switching Used by the Staff of Bali Bintang Tour and Travel". In this thesis, Jehatu used conversation between Bali Bintang Tour and Travel Staff as his data sources. He used the theory of the types of code switching proposed by Poplack (in Romaine, 1995: 122) who distinguishes types of code switching into three, i.e.,: tag switching, intrasentential switching, and inter-sentential switching. The data were explained descriptively. The result of his study showed three type of code switching and four functions of code switching were found. There are three type of code switching which are tag switching, intra-sentential switching, and inter-sentential switching. However, intra-sentential switching was the most often used at Bali Bintang Tour and Travel. Furthermore from six functions of code switching proposed by Apple and Muysken (1987) which are referential, directive, expressive, phatic, metalinguistic, and poetic, there were only four functions that applicable in this study there are referential, expressive, phatic, and metalinguistic function. In spite of taking the same topic for the study, the data source in the study is difference. In his study Jehatu used data sources from the communication of Bali Bintang Tour and Travel staff to their guests. In this study, the writer used data source from Ripcurl Nusa Dua focused in log book notes. It can be used as reference since the same topic on code switching is taken. This study has significant impact because some of the theories are related such as theory and function of code switching. 
There are some differences between this study and the previous researches. Those are in terms of the data source and the theory. The log book notes were used as the data source while; the previous studies used film, magazine and the communication of Bali Bintang Tour and Travel staff to their guests. Hoffman's theory (1991) was used in the previous study however, the theory proposed by Apple and Muysken (1987) and Poplack (1980) will be used to analyze the data in this study.

\section{MATERIALS AND METHOD}

\subsection{THEORETICAL FRAMEWORK}

The theoretical framework in this study was divided into two parts; they were the types of code switching and the functions of code switching. First, by Poplack in Romaine (1980) in the book entitled Bilingualism proposed the theory of the types of code switching that was used in answering the types of code switching. Second, Apple and Muysken (1987) in their book entitled Language Contact and Bilingualism proposed the theory of the functions of code switching that was used in answering the function of code switching in this study.

According to Poplack (1980) as cited in Romaine (1989), there are three types of code switching that can be identified, i.e., Tag switching, inter-sentential switching, and intra-sentential switching. Tag switching is simply the insertion of a tag in one language in an utterance which is entirely in the other language, e.g. you know, I mean, right? Due to the syntactic nature of tags, they can be inserted in many different places in an utterance without disturbing the syntactic order. This type of code switching is very simple and does not involve a great command of both languages, since there is a minimum risk of violation of grammatical rules. The following example is in Finnish/English.

(Poplack Wheeler and Westwood, 1987):

Mutta en mava vittinyt, no way!

(But I'm not bothered, no way!)

Inter-sentential switching involves a switch at a clause or sentence boundary, where each clause or sentence is in one language or another. It may also occur between speaker turns. Inter-sentential switching can be thought of as requiring greater fluency in both language than tag switching major portions of utterance must conforms to the rules of both languages. An example is taken from Puerto Rican bilingual Spanish/English speech given by Poplack (1980).

Sometimes I'll start a sentence in English y termino in espanol.

(Sometimes I'll start a sentence in English and finish it in Spanish.)

Intra-sentential switching refers to the switching that occurs inside the same clause or sentence which then contains elements of both languages. This type of switching appears to involve special principles governing how the syntax and morphology of both languages may interact and is consequently adopted only by bilinguals with high levels of fluency. An example of intra-sentential switching is taken from Tok-Pisin/English speech given by Poplack (1980).

What's so funny? Come be good. Otherwise, yu bai go long kot.

(What's so funny? Come be good. Otherwise, you will go to the court.)

The use of code switching has six functions. The six functional specializations are used to which a language maybe put or told and why the people switch between languages. However, this research prefers to use the functional model for explanation. Apple and Muysken (1987:118-120) gave some explanations about why people switch between languages through the functional model of code switching as follows

Referential function involves lack of knowledge of one language or lack of facility in that language on certain subject. Certain subject may be more appropriately to discuss in one language and the introduction of such subject can lead to switch. Hence, the entire topic related switching might be thought of as serving the referential function of a language. This type of code switching is the one that bilingual speakers are most conscious. People tend to say that they switch the language since they do not know the 
word for it in the first language or the language chosen is more precise for talking about a given subject. Scotton (1979) gives an example from a university student in Kenya, who switches between Kikuyu and English.

"Atiriri ANGLR niati HAS ina DEGREE EIGHTY; nayo THIS ONE ina miring itatu. Kuguori, IF THE TOTAL SUM OF A TRIANGLE ni ONE-EIGHTY ri IT MEANS the REMAINING ANGLR ina ndigirii mirong mugwanya"

In another example:

nanti saya berhenti mobilnya di painting house.

(I will stop the car at the painting house)

(Kanisius Jehatu, 2011. Thesis "An Analysis of Code Switching Used by the Staff of Bali Bintang Tour and Travel" page 30).

Referential function can be categorized in this code switching because the use of the name of the house and it is impossible to change in Indonesian.

Directive function involves the hearer directly. It is used to exclude certain person in a conversation. The opposite side includes a person more by using her or his language. A person may have joined the participants and an interaction. The simple example is also given by Apple and Muysken (1987) such as many parents try to speak foreign language when they do not want their children to understand what is being said. If they do this too often they find out that the children to understand what is being said. If they do this too often, they find out that the children have learned the second language as well.

Mereka tengah mengobrol sambil mencicipi kue ketika aku datang yang memang bertepatan dengan waktu tea morning.

(Roidah, 2004.Novel "Love Me, Save Me page 232).

Regarding the function of code switching, the code switching in data above serves directive function. The English word "tea morning" is used by the writers to make the readers understand what is being said. Switching here is used because there is an involvement of the hearers directly.

Expressive Function is namely the switching which shows the speakers who are emphasize a mixed identity through the use of two language in the same discourse. For example is Spanish-English code switching in Puerto Rican community. For fluent bilingual Puerto Rican in New York, conversation full code switching as a mode of speech by itself and individual switches no longer have a discourse function. This function may not be present in all code switching communities.

Phatic function is to indicate a change in tone of the conversation; the type is also called as metaphorical switching by Gumperz and Hernandez-Chavez (1975). It can see from the stand up comedian that tells the whole joke in a standard variety, but it has brought the punch line a vernacular type of speech. This type of switch has been documented extensively in a paper on switching between London Jamaican and London English by Sebba and Wootton (1984). In which a stretch basically of Jamaican discourse. When Jamaican fragments are inserted in to an English context, the main functions seem to be that on highlighting conveyed. An example: English "Meta-comment".

m:an...Leonie'ave party... WHEN... DON'T REMEMBER WHEN IT WAS bots hi did telaal o dem no fi

(t) se notin... kaaz shi no waan tu moch Cat ford gyal di de... an Jackie av wan tu... neva se notin.

Metalinguistic function occurs when it's directly or indirectly used to comment on the language involved. It's happen when speakers speech between different codes in order to impress the other participants with a show a linguistic skill. (Scotton, 1979 in Apple and Muysken 1987:120). Many examples of this can be found in the public domain: performers, circus, directors, and market sales people.

Hei great couple! sapa Rio ketika kami sampai di hadapannya.

(Roidah, 2004. Novel "Love Me, Save Me page 215).

The data above can be categorized as serving metalinguistic function, because by switching the code, it means that the writer wants to comment directly the topic which is being discussed. The use of word "Hei great couple!" also impresses the complement of the couple. 
The function emphasizes the use of bilingual language involving switches puns, jokes, etc. An example is quote from Ezra Pound's Canto XIII (1980).

Yu-chan to pay sycamores

Of this wood are lutes made

Ringing stones from sey choui river

And grass that is called Tsing-mo 'or

Chun to the spirit Chang Ti, of heaven

Moving the sun and the stars

Que vos vers experiment vos intentions

Et que la musique conforme

Pound works with complex internal rhymes across languages: Chinese Gods, rivers, emperors, and mountains are matched with elements from Homerik Greek and French, Italian, or Provencal verse. The result is at once an erudite evocation of all human civilizations and Panolpy of sounds.

\subsection{RESEARCH METHOD}

The method used in this research was the way to analyze and to get the data. It was one of the efforts to find and examine the truth of a science for which method is used. The analysis depended on the relationship of method and objective. This chapter focused on the data source, data collecting, data analysis, and finding presentation.

The data source of this study was taken from Ripcurl Nusa Dua log book notes made by the staffs. Who write their log book was vary there were manager, supervisor, staff sales assistant and cashier. Ripcurl Nusa Dua located at Bali Collection Blok B04 BTDC Area, Nusa Dua. The data was taken during March 2016 to April 2018. This data source was chosen through some reasons. First, Ripcurl is one of big surfing brand companies in the world. And the second one, employees of Ripcurl in Bali are mostly Indonesian people who will not always speak in English towards their colleague around their workplace. Furthermore, they tend to do code switching in their daily conversation whether it is written such as in the log book or spoken

In this research the data was collected by using observation method through note taking techniques. The data was taken from Ripcurl Nusa Dua log book notes. Therefore, the observation was conducted in several techniques such as reading and note taking. Descriptive qualitative method was used to analyze the data. The analysis was conducted through several steps. First, the theory proposed by Poplack (1989) was used to classify the types of code switching produced by Nusa Dua Ripcurl log book. Furthermore, the theory of the function of code switching developed by Apple and Muysken (1987:118-120) was used to analyze the function of code switching.

\section{RESULTS AND DISCUSSION}

From the data log book notes in Ripcurl Nusa Dua, there are three types of code switching were found. The analysis is described based on the types of code switching. Thus, the analysis is divided into three sections. Those are tag switching, inter-sentential switching, and intra-sentential switching. In analyzing data, there are two steps that were done. First, determining the types of code switching that occurred in the data and then, the analysis presented one by one according to the each type and give the example that is produced from the utterance of log book in Ripcurl Nusa Dua. The function of code switching is described in the analysis of each data. 


\subsection{Tag Switching}

Tag switching occurs when in the utterance involves the insertion of an exclamation, a tag or parenthetical in one language into an utterance which is otherwise entirely to other language. The data can be presented as follow.

Data 1

"Yes please, apa yang saya bisa bantu untuk anda?"

(Log book noted, Ripcurl Nusa Dua, Cara menghandle customer, 18 November 2017).

In the noted here was found the sentence "Yes please, apa yang saya bisa bantu untuk anda?" The manager here made a note to tell the staff sales assistant how to handle the customer. The phrase "yes please" indicate a tag switching that added in the front of sentence. "Yes please" was a phrase that commonly used by Staff Sales Assistant to offer his or her helping to the customer/guest. The words "yes please" actually can be translated into Indonesia; the utterance "yes please" can be translated into "silahkan". Based on the theory of Apple and Muysken, the phrase "yes please" refer to metalinguistic function, which was Indonesian language used after "yes please" to make sure the guest understand in English or not and he want to impressing his ability in order to show ability by used in English language.

Data 2

"Sorry, saya belum bisa menjelaskan apa yang terjadi di perusahaan ini. Jadi tetap semangat ya dengan penjualan nya".

(Log book noted, Ripcurl Nusa Dua, 03 Oktober 2016).

In the log book note was found the sentence "Sorry, saya belum bisa menjelaskan apa yang terjadi di perusahaan ini. Jadi tetap semangat ya dengan penjualan nya". The note here was given directly to the staff from the manager, but the manager has not been able to explain what was going on inside the company by starting word "sorry". Here "sorry" was also regarded as a tag switching because it refers to exclamation. However, the word "sorry" has its appropriate translation in Indonesian language, but the writer did not use it. The writer tended to switch it replacing word "maaf" because its sound more friendly. Therefore, dealing with the sentence, the tag can be categorized as metalinguistic function because he wanted to show linguistic skill by using word "sorry" and also referential function occurred in this utterance because the writer's lack of knowledge in one language.

\subsection{INTER-SENTENTIAL SWITCHING}

According to Poplack (1980) as cited in Romaine (1989), Inter-sentential switching involves a switch at a clause or sentences boundary, where each clause or sentence is in one language or another. This inter-sentential switching also can be call inter-sentential code alternation and depends for the speaker or the writer uses more than one language. This kind of switch is requires to more betters in use both language. This inter-sentential switching is categorized:

Data 3

"Setelah tamu sampai di kasir. Please check before transactions."

(Log book noted, Ripcurl Nusa Dua 02 Mei 2016).

The utterance was categorized as inter-sentential switching because of the use of Indonesian in one clause (the beginning of utterance) and another language (English language). Here the manager gave note to staff sales assistant and cashier to check the items before the transaction. In this utterance, we can see that the writer of the noted in log book used English at the end of utterance to show his mastering English by using "Please check before transactions". This utterance can be identified as metalinguistic function and phatic function Metalinguistic occurs when speakers switched between different codes to impress the other participants with a show of linguistic skill and also phatic function occurred in this utterance because the manager wanted to emphasize the staff directly that before transaction must check the item.

Data 4 


\begin{abstract}
"Untuk tamu yang membayar memakai mata uang asing ingat dimasukakan ke DCC apabila tamu membayar memakai visa (kartu) tetapi di faktur muncul maestro tolong dimasukkan sesuai fakturnya). If it is not clear please ask to leader in charge".
\end{abstract}

(Log book note, Ripcurl Nusa Dua, 29 Desember 2016).

In the sentence above, the manager used an Indonesian language: "Untuk tamu yang membayar memakai mata uang asing ingat diinput ke DCC apabila tamu membayar memakai visa (kartu) tetapi di faktur muncul maestro tolong diinput sesuai fakturnya (debet tapi di fisik visa)". Inter-sentential switching can be found here in sentence "If it is not clear please ask to leader in charge" because of the use of English in one clause (in the last of clause). In this case metalinguistic function occur automatically because the writer wanted to show his mastering in English and also phatic function can be identified in this utterance where here the writer consciously emphasize the utterance by using English in the last sentence to warn the staff to ask to the leader in charge if they do not understand.

\title{
3.3 INTRA-SENTENTIAL SWITCHING
}

Intra-sentential switching involves arguably, the greatest syntactic risk, and maybe avoided by all but the most fluent bilinguals. It occurs within the clause or sentence and word boundary.

Data 5

"Saat hendak pulang meninggalkan floor, tolong untuk team sales yang serah terima, lakukan double crosschecks lagi."

(Log book, Ripcurl Nusa Dua, 02 Mei 2016).

The utterance above was categorized as intra-sentential switching because the used of some words in other language (Indonesian) between English language. The manager gave warning to all staff if they want to go home, please arranged a good handover. The utterance "floor, team sales and double crosschecks" actually can be translated into Indonesian, but the writer use English instead of Indonesian. For the function of code switching which can be categorized in this utterance is referential function because involves lack of knowledge of one language and he usually uses those words in his daily activities, if it is changed the reader will be confused to read it. So, it is a little bit hard for him to change it.

Data 6

"Tolong pastikan untuk semua team, selalu di update produk yang ada hitungannya seperti jam, kacamata, dan dompet".

(Log book note, Ripcurl Nusa Dua, 28 Juli 2017).

In the log book note the manager gave warning to the all staff by statement "Tolong pastikan untuk semua team, selalu di update produk yang ada hitungannya seperti jam, kacamata, dan dompet" This fact showed that the writer wanted to involve and emphasize to the reader (staff) directly that it means the all staff must updated and controlled the product. Showing in that utterance, the writer to make the reader more understand about his information.

The utterance above was categorized as intra-sentential switching because the use of some words in other language (English) between Indonesian language. The words "update" it means a thing that "diperbaharui". The writer inserted any other word from different language because the word "update" is very familiar in communities. The writer used the word because the writer's lack of knowledge in one language. Therefore, make it is easier to be understood by reader. So, it can be identified as referential function and metalinguistic function occurs in this utterance because he wants to show owned ability by using in English. 


\section{CONCLUSION}

There were three types of code switching found in the notes made by the staffs in Ripcurl Nusa Dua namely tag switching, inter-sentential switching, and intra-sentential switching. Tag switching occurred when in the utterance involves the insertion of an exclamation, a tag or parenthetical in one language into an utterance which is otherwise entirely in the other language. Inter-sentential switching involves a switch at a clause or sentence boundary, where each clause or sentence is in one language or other language. Intra-sentential switching involves, arguably, the greatest syntactic risk, and may be avoided by all but the most fluent bilinguals.

Having done the analysis of functions in the notes made by the staffs in Ripcurl Nusa Dua based on the theory of Apple and Muysken (1987), it was found that not all of six functions were available. Metalinguistic function, referential function and phatic function were applicable found in the notes made by the staffs in Ripcurl Nusa Dua. Those functions occurred when the staffs to show his linguistic skills, involves lack of knowledge of one language or lack of facility in that language on certain subject and wanted to emphasize the messages when change the tone.

The factors led the staff code switch is because the staffs found that the English term is easier to remember or better to be understood than in Indonesian term. Sometimes they do not know the Indonesian language or the term Indonesian when they expressed it, they only used one word English or one phrase not completed one clause when talking or revealing something. Also, the staffs in Ripcurl Nusa Dua has ability in using English or bilingual and wanted to show his linguistic skill in order to get attention or appreciation from their bos or manager which can help them to reach a better position in company.

\section{REFERENCES}

Apple, R. \&Muysken, P. 1987. Language Contact and Bilingualism. London: Edward Arnold Grosjean, Francois. 1982. Life with Two language. Combridge: HarvardUniversity Press.

Hornby, A.S. 1965. Definition note. Available from: http://en.oxforddictionaries.com/definition/note. Retrieved on 17 February 2018

Hudson, R.A. 1980. Sociolinguistic. Melbourne Cambridge Univ Press.

Hymes, D. 1974. Foundation in Sociolinguistics: An Ethnographic Approach. Phildadhelpia:University of Pennsylvania.

Jehatu, Kanisius. 2011 An Analysis Of Code Switching Used By The Staff Of Bali Bintang Tour And Travel. Thesis. Denpasar. English Study Program, STIBA Saraswati Denpasar.

Karimah, Ukhfiyatul. 2011. English Code Switching And Code Mixing Found In Advertisements Of Kompas In The First Week Of July Edition 2011. Thesis. Kudus: Department Of English Education Faculty Of Teacher Training And Education, University Of Muria Kudus.

Oktavina, Sukma. 2013. An Analysis Of Code Switching Used By Hashim As A Character In Film Entitled Java Heat. Thesis. Yogyakarta: English Education Department Languages And Arts Faculty Yogyakarta, State Univertsity.

Oxford, 2018. Definition Staff Available from: https://en.oxforddictionaries.com/definition/staff. Retrieved on 30 June 2018

Pride, J.B. \& Janet Holmes. 1972. Sociolinguistics. England: Penguin.

Roidah. 2004. Love Me, Save Me. Jakarta: Dive Press.

Romaine, Suzane. 1989. Bilingualism, second edition. Oxford: Blackwell Publisher. 